\title{
Promoting Environmental Education at the Geographical Space of the Pati Cua Stream" Basin
}

\author{
Palavecino José, Eibl Beatriz, Lopez Jorge, Centurión Diego, Aguinagalde Santiago, Vier Fernando, \\ Barrios Hector
}

Faculty of Forestry Ciences, National University of Misiones - Eldorado, Posadas, Argentina

Email address:

pala@facfor.unam.edu.ar (P. José)

To cite this article:

Palavecino José, Eibl Beatriz, Lopez Jorge, Centurión Diego, Aguinagalde Santiago, Vier Fernando, Barrios Hector. Promoting Environmental Education at the Geographical Space of the Pati Cua Stream' Basin. American Journal of Agriculture and Forestry. Vol. 5, No. 6, 2017, pp. 188-191. doi: 10.11648/j.ajaf.20170506.12

Received: September 20, 2017; Accepted: November 9, 2017; Published: December 1, 2017

\begin{abstract}
The obtained results at the studies previously made on the Pati Cua basin (Eldorado, province of Misiones), reveal a slow deforestation of the Paranaense Forest (Atlantic Forest); with the aggravating of the biodiversity loss and the elimination of the protective forests, which turns into a severe warning about the quality of the water, due to anthropic activities. After seeing this panorama, the need for address the problem emerged and there were made several necessary actions in order to make people aware of it, and to reestablish the environmental balance; working side by side with the people and institutions inserted at the geographical space of the basin. Into the main objectives for this Environmental Education' project, it is the one about to encourage an interinstitutional approaching for the environmental education linking University - Schools - Municipality and Neighborhood Commissions. The lines of actions were: masterly classes at schools, replanting of several native species at the stream coasts, and an active participation in schools' Science Fairs, among others. And of all the obtained results, it is remarkable the continuous formation of the teachers and students facing the problematic; the elaboration of educative material; several distinctions at the Science Fairs; implantation of essays about native species at the stream coasts; the commitment of the neighborhood commissions for the protection of the forests; and the continuation of the exhibitions concerning environmental education. As a conclusion, it is affirmed that the actions done generated a high commitment level by every intervenient sector. Of the students involved, it is remarkable their determination to continuing the lines of action; as for their teachers, it is notable their permanent formation and approaching on the environmental topic into the curricular contents. And for the institutions, it is manifested a high commitment level on continuing the planned lines of action, in order to improve the life' quality at the geographic space of the basin of the Pati Cua stream, and its influence area.
\end{abstract}

Keywords: Environmental Education, Hydrographic Basin, Pati Cua Stream, Misiones

\section{Introduction}

Environmental Education (EA) is a process in which are formed both knowledge and commitment to lead people to rethink their relation with the environment. Their attitude changes in favor of improving the quality of life of their society, could implicate the survival of both animal and vegetal species; and consequently, to help to preserve life in our planet. And schools, sources for the production and formation of knowledge, are the genuine channels to be used in the making of this process. EA presupposes an interdisciplinary work; that is, a knowledge construction process that considers every single aspect, allowing a holistic vision for the learned content. In this context, one of the studied units for the EA project is the hydrographical basin. It is a physical unit considered as "ideal" for a better control and management of the environment. It results in a very effective unit for an interdisciplinary approach which ranges from schools (both teachers and students) to neighborhood commissions. Nowadays, the land uses made through urbanization and agricultural activities are provoking several different impacts into the environmental, economic and social aspects. Those impacts have repercussions into the performance of the hydrological cycle, mainly through deforestation, affecting both animal and plant biodiversity, 
making the natural ecosystems disappear, and diminishing the biomass production. The Paranaense forests doesn't evade this problem, and the periodic observation of its condition by satellite imagery shows a notorious fading of the green covertures. Among all the hydrographical basins at Eldorado (province of Misiones), the Pati Cua stream' basin located to the northeast of the region, is one of the few basins that still have a relatively high ratio of vegetal coverture, compared with surrounding basins. However, the obtained results from a diagnostic study of the protective forests along the water streams reveal a slowly deforestation, with the aggravating of the biodiversity loss; and a severe warning about the water quality, due to anthropic activities, waste dumping and inefficient agricultural practices. After the analysis of the data, it appears the necessity of approaching the problematic through several necessary actions, in order to reestablish the environmental balance; working side by side with the population and institutions inserted at the geographical extension of the basin. And that's how the Project on EA at the basin of the Pati Cua stream, which tries to accomplish the basic Principles for the EA known as Sensitization, Responsibility, Competence and environmental citizenship (Smith \& Sato, 1995). It was established as a main objective to be able to achieve an interinstitutional approaching for the EA, linking together University Schools - Municipality and Neighborhood Commissions. At the first stage, the objectives were aiming to encourage the defense for the environment (a); to promote an attitude change regarding to the management of the natural resources and waste disposal (b); to identify tropical diseases, their vectors and ways of prevention (c); to link up the educational institutions to the government' prevention activities, regarding to environmental problems and the control of diseases.

\section{Methodology and Approaching}

The methodology consisted of masterly classes and activities for both students and teachers, regarding to the keeping of the environment, and its polluting agents. There, the students from the Biology Teacher career of the Faculty of Forestry Sciences of th National University of Misiones (UNaM) exposed about the characteristics of tropical diseases as dengue, lehismaniasis, malaria and yellow fever; which appeared at the province of Misiones. Those expositions were made in three stages: a) informative, that included the identification of polluting agents; b) narrative, that included photo galleries, cases description, and notes from newspapers; and c) preventive, that included the making of monographies, outreach brochures, and divulgation of the information at science fairs.

\section{Actions}

\subsection{Informative}

This stage consisted of the identification of the hydrographical basin of the Pati Cua stream; the neighborhoods inserted at it; and the geographic position of the participant schools at the project. At first, there were made several masterly classes to the teachers, and tours at the geographical space of the basin (Figure 1).

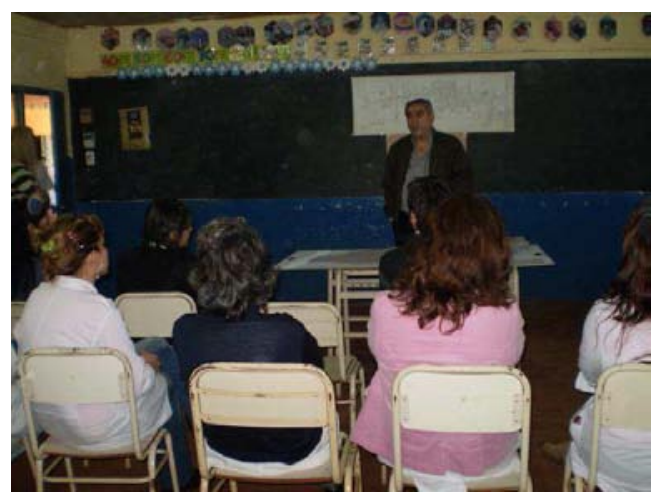

Figure 1. Identification of the basin and neighborhoods in cartography.

The next step of the informative stage was the identification of the stream' pollution sources at the basin. In the tours, there were identified several dumps, and other kinds of garbage disposal (Figure 2). And the final step was the identification of the polluting agents (Figure 3).

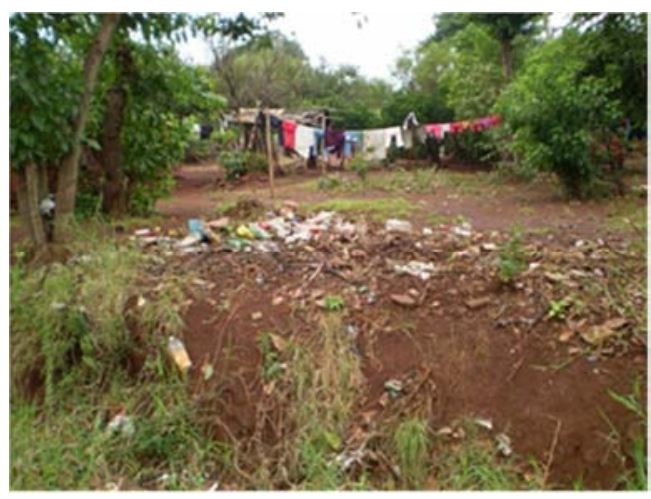

Figure 2. Garbage disposal at the stream coastline.

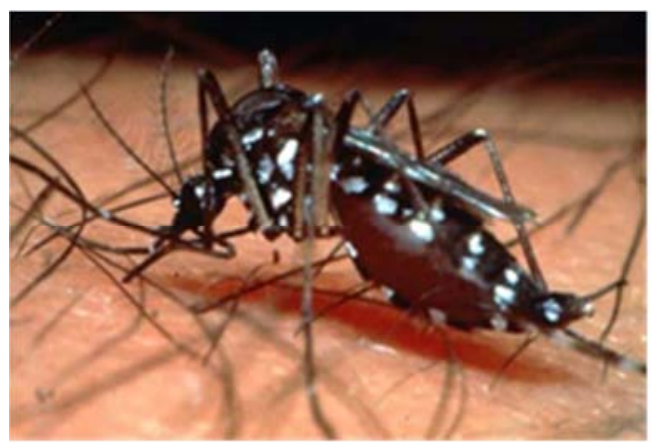

Figure 3. Aedes aegipti, a vector of dengue and yellow fever diseases.

\subsection{Narrative}

Considering that the water is one of the main vehicles for the spreading of pathogens, this stage consisted on the reading of water pollution cases, from notes from local and provincial newspapers (Figure 4). 


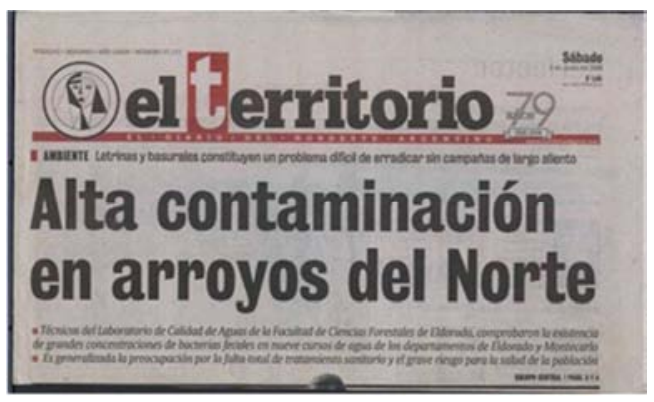

Figure 4. Note from a local newspaper about water streams pollution.

\subsection{Prevention}

This third stage was made mainly through masterly expositions about diseases, by students of the Biology Teacher career (Figure 5). It were designed, printed and distributed outreach brochures; together with the ones made by the Ministry of Public Health of the Province of Misiones. At this stage, some acting was performed. Nowadays, the dramatization, the stories telling, surprises and humor are powerful tools if used as pedagogic resources. The characteristic of theatre as a visual way of communication turns into the closest approximation between the sender and the receiver of the message. Those dramatizations were performed by "actors" (the students), who represented some local stories about tropical diseases in humans (Figure 6).

Also, it is remarkable the teaching of the right way for washing hands, according to the WHO (World Health Organization), and the planting of trees at the schools parks.

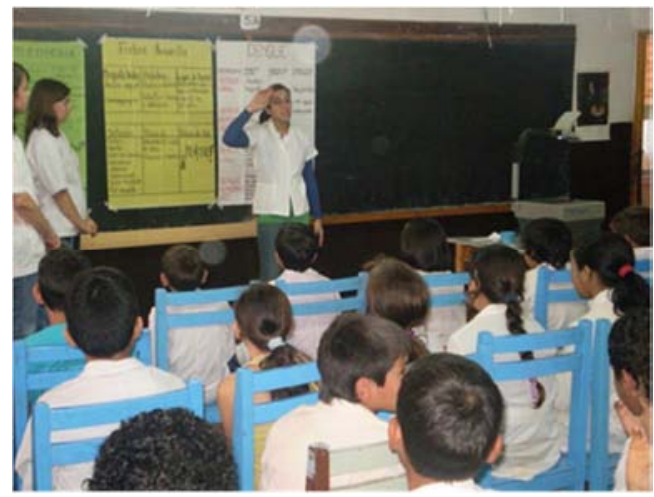

Figure 5. Exposition on tropical diseases by students of the Biology Teacher career.

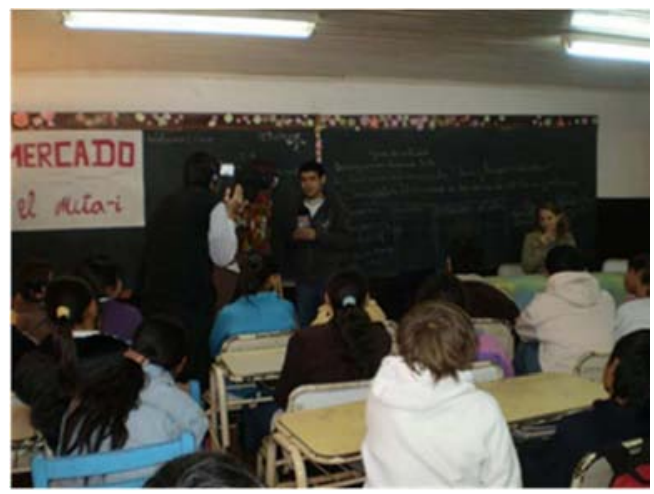

Figure 6. Dramatization about garbage disposal, at a local school.

\section{Results}

The project included five primary schools: Provincial School $n^{\circ} 880$, Provincial School $n^{\circ} 745$, Provincial School $\mathrm{n}^{\circ}$ 858, Provincial School $\mathrm{n}^{\circ}$ 668, and the Provincial School $\mathrm{n}^{\circ} 165$; in which up to 20 teachers participated in the formation classes, and up to 300 students participated of the presented expositions. It is also remarkable the participation of the Sanitary Agents of the Ministry of Public Health of the Province, and the members of the neighborhood commissions. Even more, five students were incorporated to dramatizations; and became "sanitary agents" and spokesmen in favor of the care of the environment, in their own houses and neighborhoods. Every stage for the planting of trees species both in schools and in the stream coasts, were made in a number of 25 ( 5 in every school); and 12 different native species at the streams coasts. It is highly remarkable the expositions made by students at the science fairs, where different environmental problems and diseases prevention were presented, in every one and each of the participant schools. Within the curricular subjects, the students were in charge of carrying out a variety home works, as graphics, drawings, photos (Figure 7) and videos related to the environment and biodiversity; as visual media database for the confection of the informative brochure. The participant students made tours at the "Selva Misionera" Botanical Garden, located at the Faculty of Forestry Sciences, in order to learn to recognize several native species. The progresses of the project were presented at different expositions made by the National University of Misiones; moreover, it was also presented at the National University of the Center, province of Buenos Aires (Figure 8).

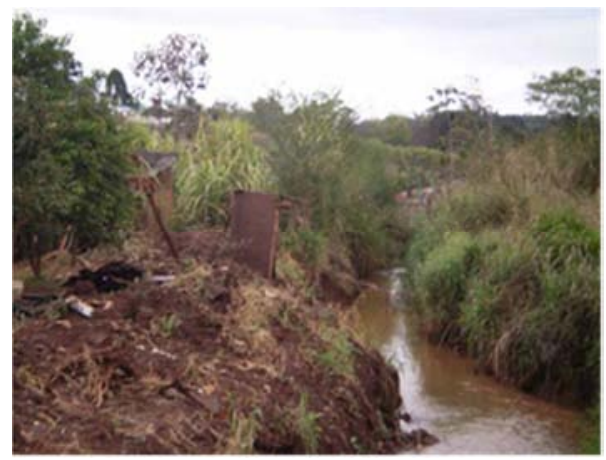

Figure 7. Latrines over the stream coasts (photo made by a student).

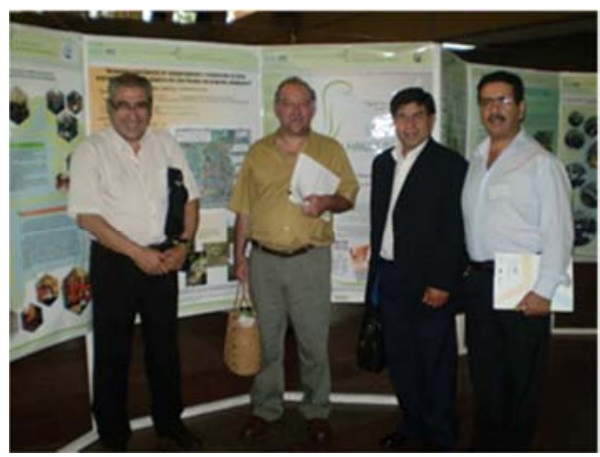

Figure 8. Presentation of the progress of the project. 


\section{Conclusions}

As a main conclusion, it is affirmed that the activities made generated a very high commitment degree, by every intervenient actor on this project. At a student level, it is remarkable the effort to participate on the restauration activities for the protective forests, and in the works presented at the science fairs. At a teachers level, it is denoted a continuous formation, and the incorporation of the problematic into the curricular subjects. At an interinstitutional level, it stands out the high commitment degree of the parts, in continuing the projected actions in order to improve the quality of life in the area of influence of the Pati Cua stream basin. It is also emphasized an effective work of every institution involved: Municipality, Ministry of Health, Neighborhood commissions, University and schools. It was obtained a lot of new information about pathogen germs and data interpretation about water quality. Besides, due to this project, it was possible the marking of new walking paths and the realization of workshops into the "Kuppers Fall" and "Virgin Mary of Pati Cua" reserves. Nowadays, this project is in an extension stage, in which the bird watching activity is a main objective, regarding to the animal component of the project for the area. Also, this project is well known as a pioneer action for the EA regarding to hydrographical basins of the region. It is highly remarkable the social impact obtained through the activities made by this project; as a way of revaluing the local biodiversity of the location.

\section{References}

[1] SECRETARY OF NATURAL RESOURCES \& SUSTAINABLE DEVELOPMENT. Presidency of the Nation, 1999. Base for the National Strategy to the Environmental Education, Argentina.

[2] CAMPANER G.; VALEIRAS, N. 1992, School Commitment into the Environmental Problems: A Neighborhood Experience (Córdoba).

[3] CARIDE J. A.; MEIRA, P. A. 2001, Environmental Education \& Human Development. Ariel, Barcelona.

[4] Di FIDIO. M. 1985, Architettura del paesaggio, Milán, Italia.

[5] MEC/SEF. 1998, Parâmetros Curriculares Nacionais: meio ambiente e saúde, Secretaria de Educacao Fundamental, Brasília.

[6] MINISTRY OF NATURAL ENVIRONMENT. 1999, White Book for the Environmental Education, Publication Center of the Technical General Secretary for the Natural Environment. Technical Commission for the Environmental Education. Spain.

[7] ORELLANA. L. 2001, Learning Community for Environmental Education. Topics on Environmental Education.

[8] RAISZ, E. 1953, General Mapping, Ed. Omega, Barcelona.

[9] REBORATTI, C. 1999, Natural Environment \& Society: Concepts \& Relations. Ariel, Buenos Aires.

[10] SATO, M. 1995, Environmental Education, Sao Carlos: UFSCar/ PPG-ERN, Brasil.

[11] INTERNATIONAL SEMINARY OF ENVIRONMENTAL EDUCATION, 1977, Anais. Belgrado.

[12] VIEIRA, L. S. 1988, Manual da Ciência do Solo, com ênfase aos solos tropicais. Editora Agronômica CERES, São Paulo. 